\title{
Water Soluble Fraction of Crude Oil Uncouples Protease Biosynthesis and Activity in Hydrocarbonoclastic Bacteria; Implications for Natural Attenuation
}

\section{Atim David Asitok ${ }^{1}$, Sylvester Peter Antai ${ }^{1}$, Maurice George Ekpenyong ${ }^{1}$}

${ }^{1}$ Environmental Microbiology and Biotechnology Unit, Department of Microbiology, Faculty of Biological Sciences, University of Calabar, P.M.B.1115 Calabar, Nigeria

\begin{abstract}
Three hydrocarbonoclastic bacteria isolated from crude oil-impacted mesotidal waters of the Niger Delta area of Nigeria, and identified, by 16S rRNA sequencing, as Vibrio fluvialis OWPB63, Serratia sp. MWPB18 and Pseudomonas fluorescens OWPB17 demonstrated commendable protease production ability in skimmed milkminimal medium. Protease biosynthesis commenced in all three bacteria before the first $2 \mathrm{~h}$ of fermentation with peak productivities of 4.12, 0.73 and $1.12 \mu \mathrm{g} / \mathrm{mL} / \mathrm{h}$ reached at 12,36 and $48 \mathrm{~h}$ for Vibrio fluvialis, Serratia $\mathrm{sp}$. and Pseudomonas fluorescens respectively. Activities of the enzymes assessed with azocasein as standard substrate were respectively $116.61,174.56$ and $145.84 \mu \mathrm{g} / \mathrm{mL} / \mathrm{min}$. Median inhibition concentration (IC50) for Vibrio fluvialis enzyme biosynthesis, significantly $(P<0.05,0.01)$ influenced by exposure time, was $<10 \%(<0.91 \mathrm{mg} / \mathrm{L})$ with a corresponding IC50 for protease activity of $<50 \%(<4.55 \mathrm{mg} / \mathrm{L})$. This suggests that protease biosynthesis was more amenable to toxicity by WSF than its activity. Supplementation of respective crude bacterial proteases in pureculture biodegradation medium containing casein-N significantly $\left(P=0.005 ; R^{2}=0.9914\right)$ enhanced hydrocarbonoclasis, however only $13.8 \mathrm{mg} \mathrm{C}-\mathrm{CO}_{2}$ was evolved in the mixed-culture study as against $98.4 \mathrm{mg}$ in the control containing $\mathrm{NH}_{4} \mathrm{Cl}$. These findings imply that inhibition of bacterial protease biosynthesis by WSF of crude oil reduces nitrogen availability thus limiting natural attenuation opportunities oil-spilled aquatic ecosystems.
\end{abstract}

Keywords: Crude oil; Water soluble fraction; Protease; biosynthesis, Toxicity; Vibrio fluvialis OWPB63

\section{Introduction}

Hydrocarbon pollution of the Niger Delta region of Nigeria is a major environmental problem owing to the frequency of oil spills from oil tanker accidents and pipeline blow-outs in the area $[4,8]$. Opinion polls are largely in support of the native community's dissatisfaction with government programmes in the area as a major reason for oil-producing area restiveness [16]. As a remedial measure, attempts have been made by government as well as nongovernmental organizations to remediate especially contaminated agricultural soils and near-shore/coastal recreational beaches [22]. The gold standard remediation strategy adopted for clean-up of hydrocarbon-polluted aquatic systems is bioremediation, in view of the very nature of the system and environmental compatibility $[4,15]$.
Bioremediation is defined as an engineering technique that employs the science of biological, especially microbial, degradation to remove or detoxify organic and inorganic pollutants from environments. The rate and extent, which underlie the success of microbial degradation of hydrocarbon pollutants, is grossly influenced by a number of abiotic factors [15]. Essentially, nutrient elements like phosphorus and nitrogen are required for synthesis of nucleic acids and hydrocarbon-degrading enzymes respectively. It is an established fact that the availability of nitrogen limits hydrocarbon degradation by microorganisms in estuarine, marine and freshwater habitats because of the tendency to be washed out in these open systems [13] A remarkable synergistic association between proteolytic microorganisms and their hydrocarbonoclastic counterparts exist in crude oil-polluted environments;

This article is published under the terms of the Creative Commons Attribution License 4.0

Author(s) retain the copyright of this article. Publication rights with Alkhaer Publications.

Published at: http://www.ijsciences.com/pub/issue/2017-07/

DOI: 10.18483/ijSci.1344; Online ISSN: 2305-3925; Print ISSN: 2410-4477 
the proteolytic group serving to supply nitrogen from bound complex proteinacous materials in the form of ammonia.

Proteases or peptidases are hydrolases that catalyze the hydrolytic cleavage of peptide bonds in proteins with the sole objective of reducing substrate complexicity thereby facilitating the activities of deaminases to make $\mathrm{NH}_{3}$ available in the environment. In aquatic systems, freshwater or marine, concentrations of $\mathrm{NH}_{3}$ are almost always low [13] and as a result, biodegradation of organic matter is grossly limited. Dead aquatic lives are continuously putrefied in aquatic environments by proteolytic microorganisms especially bacteria and fungi, to increase the supply of ammonia and reduce carbon-nitrogen $(\mathrm{C}: \mathrm{N})$ ratio to facilitate biodegradation of hydrocarbons or other organic compounds.

In the Qua Iboe estuary where there is chronic input of Qua Iboe light crude oil arising from various oil activities, the coastlines of Utan Iyatah and Okposo are chronically impacted with crude oil making recreational and domestic uses of the water impossible. A great diversity of hydrocarbonoclastic microorganisms, mostly bacteria, yeasts and molds $[1,8]$ have been isolated from the area and their densities, biodegradation potentials and capabilities demonstrated, yet the waters remain polluted after several months to years of hydrocarbon impact. Physicochemical activity studies conducted in the area reveal low $\mathrm{pH}(\leq 5.00)$ suggesting low levels of ammonia arising from poor availability of peptides and amino acids. The carbon-nitrogen ratio $(\mathrm{C}: \mathrm{N})$ is extremely high throughout the year making natural crude oil attenuation in the environment impractical [12].

This research sought to provide answers to begging questions such as; (i) how does protease biosynthesis fare in the face of crude oil challenge? (ii) Are the activities of proteases inhibited even after synthesis? (iii) What are the implications of inhibition of protease biosynthesis and/or protease activity on microbial degradation of crude oil? Our toxicant was water soluble fraction (WSF) of crude oil which is the fraction of the oil that readily dissolves in water at room or accelerated temperatures. It constitutes the fraction that is biologically available and hence responsible for mediation of toxicity or otherwise in biological systems. The results of this research will provide solutions required to address the poor natural attenuation potential of the impacted coastlines of Utan Iyatah and Okposo in the Niger Delta area of Nigeria.

\section{Materials and methods}

\subsection{Site description and sample collection}

Crude oil-impacted samples, comprising 3 water and 3 sediment, were collected from the marine waters of Okposo and Utan Iyatah, along with 3 un-impacted samples from neighboring waters of Mkpanak creek in Qua Iboe Estuary of the Niger Delta region of Nigeria along coordinates $4^{\circ} 35^{\prime} 14.9^{\prime} \mathrm{N}, 008^{\circ} 17^{\prime}$ $0.16 \mathrm{E}, 4^{\circ} 40^{\prime} 49.6^{\prime} \mathrm{N}, 008^{\circ} 1745.4^{\prime} \mathrm{E}$ and $4^{\circ} 32^{\prime} 20 \mathrm{~N}$, $7^{\circ} 59^{\prime} 28 \mathrm{E}$ for Okposo, Utan Iyatah and Mkpanak respectively (Figure1). The sampling points are coastal zones along the mesotidal waters of the Bight of Bonny in Akwa Ibom State that make up the south eastern flank of the Niger Delta region of Nigeria [8]. Sampling points were located by means of the Global Positioning System (GPS) $200 \mathrm{~m}$ one from another within each point. Water samples were collected with sterile sampling bottles while epipellic sediment samples were collected by means of the Shipek Grab sampler into sampling bottles. The samples, properly labeled, were transported to the laboratory for microbiological analyses in ice-packed coolers to forestall drastic changes in critical environmental parameters.

\subsection{Sample preparation and microbiological analyses}

The 12 samples were pooled into 6 composite samples, each sampling location having two composites; Sediment and Water. All samples were prepared by 10 -fold serial dilutions from initial $10 \mathrm{~g}$ or $10 \mathrm{~mL}$ dissolution in $90 \mathrm{~mL}$ of sterile seawater. Three sets of dilutions of each sample were plated in triplicates onto freshly prepared tryptic soy agar (TSA) using the pour plate technique and incubated at $30^{\circ} \mathrm{C}$ for $36 \mathrm{~h}$. Discretely developed colonies were enumerated by means of a colony counter and morphologically-distinct colonies isolated onto freshly prepared TSA plates by means of sterile tooth-picks. All isolated colonies were purified by repeated sub-culturing onto freshly prepared TSA using the quadrant streak-plate technique. Purified colonies were maintained on agar slopes and preserved in the refrigerator until required for further studies.

\subsection{Screening of pure bacterial cultures for hydrocarbonoclastic potentials}

All purified cultures were screened for hydrocarbonoclasis in solid medium using modified vapour phase transfer method of Thijsee and van der Linden [21]. Briefly, $0.4 \mathrm{~mL}$ of Qua Iboe light crude was absorbed onto Whatman No.1 filter paper and paper placed inside the lid of a Petri dish previously seeded with $0.1 \mathrm{~mL}$ tryptic soy broth culture of each pure bacterium. All plates were incubated at room 
temperature $\left(28 \pm 2{ }^{\circ} \mathrm{C}\right)$ for $48 \mathrm{~h}$. Development of colonies on plates indicated ability to use the hydrocarbon in the vapour phase as sole source of carbon and energy.

Bacteria that tested positive to the hydrocarbonoclastic potential screen test in solid medium were secondarily tested in liquid medium. Eighteen-hour-old broth cultures of positive bacteria were introduced, at $2 \%(\mathrm{v} / \mathrm{v})$, into $50 \mathrm{~mL}$ Erlenmeyer flasks containing $9.7 \mathrm{~mL}$ of minimal medium. The medium contained $(\mathrm{g} / \mathrm{L}) \mathrm{NH}_{4} \mathrm{Cl} 1.0 ; \mathrm{MgSO}_{4} .7 \mathrm{H}_{2} \mathrm{O}$ $0.5 ; \mathrm{K}_{2} \mathrm{HPO}_{4} \quad 1.0 ; \quad \mathrm{KH}_{2} \mathrm{PO}_{4} \quad 1.0, \mathrm{CaCl}_{2} \quad 0.5$ and Seawater $1000 \mathrm{~mL}$. pH was adjusted to 7.0 with $1 \mathrm{M}$ $\mathrm{HCl}$ and $1 \mathrm{M} \mathrm{NaOH}$. Filter-sterilized Qua Iboe light crude, supplied at $1 \%(\mathrm{v} / \mathrm{v})$, served as sole carbon and energy source. The preparations were made in triplicates and flasks incubated at room temperature on an orbital shaker agitating at $120 \mathrm{rpm}$ for 16 days. Hydrocarbon utilization was assessed by spectrophotometric analysis of cell accumulation at
$600 \mathrm{~nm}$ wavelength after harvesting by centrifugation at $6,000 \mathrm{rpm}$ for $15 \mathrm{~min}$ and washing to remove residual hydrocarbon. Amount of cells was determined from a calibration curve [18].

Oil biodegradation capabilities of each successful isolate was assessed by the carbon (IV) oxide evolution method as described in Ekpenyong and Antai [6] over a 16-day period. Amount of carbon (IV) oxide was calculated using the equation;

$$
C-C O 2(m g)=(B-V) N E \quad \text { Eqn. } 1
$$

where $\mathrm{C}-\mathrm{CO}_{2}$ is the amount of carbon (IV) oxide evolved; $B$, the volume (milliliters) of acid used to titrate the alkali in carbon (IV) oxide collectors to end point in the control; $V$, the volume (milliliters) of acid used to titrate the alkali in the carbon (IV) oxide collectors to end point in the treatments; $N$, normality of acid $(\mathrm{HCl}) ; E$, equivalent weight; if data are expressed as carbon (IV) oxide, $E=22$, but if expressed as carbon, then $E=6[20]$.

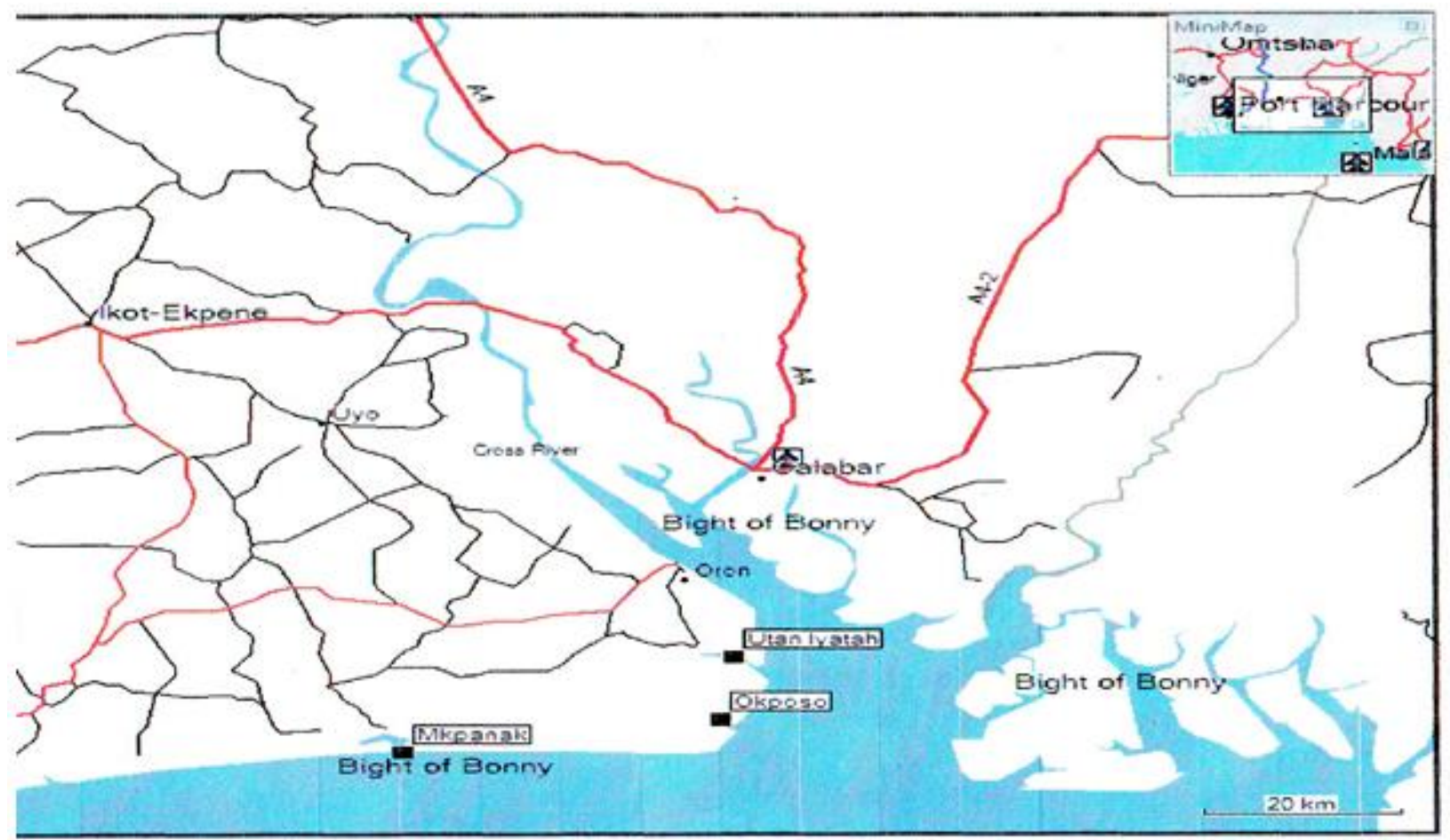

Fig. 1: Map of South-South Nigeria showing sampling locations at Mkpanak, Okposo and Utan Iyatah

\subsection{Qualitative screening of bacteria for protease production potentials}

Pure cultures of bacteria were screened for protease production by modified rapid-plate technique of Gulati et al., [10]. Screening medium was skimmed milk-minimal medium, the minimal medium of which contained (g/L) $\mathrm{NH}_{4} \mathrm{Cl} 1.0 ; \mathrm{MgSO}_{4} .7 \mathrm{H}_{2} \mathrm{O} 0.5$;
$\mathrm{K}_{2} \mathrm{HPO}_{4}$ 1.0; $\mathrm{KH}_{2} \mathrm{PO}_{4}$ 1.0; Agar-agar 15; Seawater $1000 \mathrm{~mL}$. pH was adjusted to 7.0 with $1 \mathrm{M} \mathrm{HCl}$ and $1 \mathrm{M} \mathrm{NaOH}$. The medium was supplemented with glucose $(1 \% \mathrm{w} / \mathrm{v})$ and sterilized by autoclaving at $121^{\circ} \mathrm{C}$ for $15 \mathrm{~min}$. One percent of filter-sterilized (0.45 $\mu \mathrm{M}$-Millipore) skimmed-milk was added to sterile medium at $45^{\circ} \mathrm{C}$ and contents gently swirled 
for homogenization. Each pure isolate was screened by single-line streak-plate technique on skimmedmilk plates and incubation done at room temperature $\left(28 \pm 2^{\circ} \mathrm{C}\right)$ for $36 \mathrm{~h}$. Bacteria with clear zones around lines of streak were scored positive while those that remained cloudy were adjudged negative.

\subsection{Quantitative screening of bacteria for protease production in solid medium}

Bacteria that were positive in the qualitative test were screened for preliminary quantification of protease. The medium, inoculation and incubation were as described in section 2.3 except that each bacterium was given triplicate screening. Total clear zone and colonial diameter were measured by means of a meter rule and data collated for analysis. Protease production potential (PPP) for each bacterium was determined according to the equation;

$P P P(\%)=\frac{M T Z D-M C D}{M T Z D} \times 100$

Eqn. 2

where $P P P$ refers to protease production potential $(\%) ; M T Z D$, the mean total zone diameter and $M C D$, the mean colonial diameter $(\mathrm{mm})$. Only bacteria with protease production potential of $70 \%$ and above were considered for further studies.

\subsection{Secondary proteolytic screening of bacteria in submerged culture}

Bacterial isolates that demonstrated $\geq 70 \%$ protease production potential with mean clear zone diameter of $\geq 30 \mathrm{~mm}$ in solid medium were considered for further investigation in submerged culture using the same medium in section 2.3 except that the solidifying agent (agar-agar) was excluded. Overnight tryptic soy broth (TSB) cultures of each bacterium were inoculated into $19.6 \mathrm{~mL}$ of skimmedmilk minimal medium in $100 \mathrm{~mL}$ Erlenmeyer flasks at $2 \%(\mathrm{v} / \mathrm{v})$. Flasks were incubated at room temperature on an orbital shaker agitating at $150 \mathrm{rpm}$ for $48 \mathrm{~h}$. Crude protease was harvested by centrifugation at $5000 \mathrm{rpm}$ for $10 \mathrm{~min}$ and sterilized by filtration with 0.45 and $0.22 \mu \mathrm{M}$ Millipore filters.

Detection of micro-quantities of protease in crude protease samples was performed by the Bradford method [2]. The procedure is based on the principle of protein-dye binding which brings about a colour change from light-green to blue. The protein reagent, Coomassie Brilliant Blue G-250 was prepared by dissolving $100 \mathrm{mg}$ of the powder in $50 \mathrm{~mL}$ of $95 \%$ ethanol. To this solution $100 \mathrm{ml}$ of $85 \%(\mathrm{w} / \mathrm{v})$ phosphoric acid was added. The resulting solution was diluted to a final volume of 1 liter and stored in an amber bottle.

An aliquot of $0.1 \mathrm{~mL}$ of each cell-free supernatant was transferred by means of a micropipette into $5 \mathrm{ml}$ capped tubes and the volumes adjusted to $0.1 \mathrm{~mL}$ with phosphate buffer ( $\mathrm{pH} 7.0)$. One milliliter $(1 \mathrm{~mL})$ of protein reagent was added to the tubes and contents mixed by inversion of tube. Development of blue colour indicated the presence of protein in the cell-free supernatant. All cell-free supernatants that were positive to this test were hereinafter referred to as crude protease solution and were selected for further studies.

The amount of protease in the crude protease solutions was determined by transferring $0.3 \mathrm{~mL}$ of each test solution into a test tube followed by the addition of $3 \mathrm{~mL}$ of protein reagent. The absorbance was read off a spectrophotometer at a wavelength of $595 \mathrm{~nm}$ in triplicates. Mean absorbance value was substituted into the regression equation obtained from the standard curve prepared with bovine serum albumin (Research Organics, USA) to determine the amount of protease in the crude protease solution. Bacteria that produced protease in amounts $\geq 100$ $\mu \mathrm{g} / \mathrm{mL}$ were selected for further studies.

\subsection{Identification of selected protease-producing bacteria}

The selected bacteria were identified morphologically and biochemically using the MICROGEN ID Kit (Microgen Bioproducts Limited, UK) in conjunction with Microgen identification system software as well as by $16 \mathrm{~S}$ rRNA sequencing. The sequencing protocol made use of primers 271 and 1492R and utilized a sequence mix composed of NZYTaq $2 \mathrm{x}$ Green Master Mix (Nzytech). Amplification was done by denaturation at $94^{\circ} \mathrm{C}$ for $3 \mathrm{~min}$, cooling to $5^{\circ} \mathrm{C}$ for $1 \mathrm{~min}$ and raising the temperature again to $72^{\circ} \mathrm{C}$. This was repeated through 30 cycles and then held at $72^{\circ} \mathrm{C}$ for $10 \mathrm{~min}$. The polymerase chain reaction (PCR) products were purified with the JETQUICK PCR purification Spin Kit and used as template for the sequencing reaction [7] Sequences were compared to GenBank sequences using standard nucleotide basic local alignment search tool (BLAST). The bacteria were deposited at the University of Calabar Collection of MicroorganismsUCCM, World Federation of Culture CollectionsWFCC, Reg. No.-652 (1993).

\subsection{Time-course of protease production in select bacteria}

The time-course for protease production was studied in $250 \mathrm{~mL}$ Erlenmeyer flasks. The production medium was skimmed-milk-minimal medium containing $(\mathrm{g} / \mathrm{L}) \quad \mathrm{NH}_{4} \mathrm{Cl} \quad 1.0 ; \quad \mathrm{MgSO}_{4} .7 \mathrm{H}_{2} \mathrm{O} \quad 0.5$; $\mathrm{K}_{2} \mathrm{HPO}_{4} 1.0 ; \mathrm{KH}_{2} \mathrm{PO}_{4}$ 1.0; Distilled water $1000 \mathrm{~mL}$. The medium was supplemented with $1 \mathrm{~mL}$ of trace mineral solution containing $(\mathrm{g} / \mathrm{L}): \mathrm{ZnSO}_{4} \cdot 7 \mathrm{H}_{2} \mathrm{O}$ 0.005; $\mathrm{MnSO}_{4} .4 \mathrm{H}_{2} \mathrm{O} \quad 0.005 ; \quad \mathrm{H}_{3} \mathrm{BO}_{3} \quad 0.005$; 
$\mathrm{CuSO}_{4} .5 \mathrm{H}_{2} \mathrm{O} \quad 0.005 ; \quad \mathrm{CoCl}_{2} .6 \mathrm{H}_{2} \mathrm{O} \quad 0.005$ $\mathrm{MoNa}_{2} \mathrm{O}_{4} \cdot 2 \mathrm{H}_{2} \mathrm{O} 0.005$ and $\mathrm{NiCl}_{2} \cdot 6 \mathrm{H}_{2} \mathrm{O} 0.005$ [9]. Medium $\mathrm{pH}$ was adjusted to 7.0 with $1 \mathrm{M} \mathrm{HCl}$ and $1 \mathrm{M} \mathrm{NaOH}$ and sterilization done by autoclaving at $121^{\circ} \mathrm{C}$ for $15 \mathrm{~min}$. Finally, skimmed-milk was added to the medium at $1 \%(\mathrm{w} / \mathrm{v})$ after selective sterilization by filtration $(0.45 \mu \mathrm{M}$-Millipore). Triplicate flasks, each containing $49 \mathrm{~mL}$ of medium, were inoculated with $2 \%(\mathrm{v} / \mathrm{v})$ of $18 \mathrm{~h}$-old TSB cultures of selected bacteria and incubated at room temperature $(28 \pm$ $2^{\circ} \mathrm{C}$ ) on a rotary shaker agitating at $150 \mathrm{rpm}$ for $96 \mathrm{~h}$. Protein determinations (section 2.5) were made every $2 \mathrm{~h}$ for the first $12 \mathrm{~h}$, and then every $12 \mathrm{~h}$ for the remaining $84 \mathrm{~h}$.

\subsection{Determination of protease activity}

The activity of protease was assessed in triplicates by measuring the release of trichloroactetic acid-soluble peptides from the digestion of azocasein according to the method of Vazquez et al. [25]. An aliquot of 0.2 $\mathrm{mL}$ of each cell-free broth that served as crude protease was added to three test tubes. The tubes were placed for $5 \mathrm{~min}$ in a water bath at $30^{\circ} \mathrm{C}$ for equilibration while another set of 3 enzyme-substrate blank tubes were placed on ice. Once equilibrated, $0.8 \mathrm{~mL}$ of $1.5 \%$ azocasein substrate solution (Sigma Aldrich, USA) was added to the three test tubes containing $0.2 \mathrm{~mL}$ of the crude protease to initiate proteolytic reaction. The contents of the enzymesubstrate sample tubes were gently mixed and incubated for $10 \mathrm{~min}$ while the other set of enzymesubstrate blank tubes were placed in the $30^{\circ} \mathrm{C}$ water bath to equilibrate. At the end of the $10 \mathrm{~min}$, proteolytic reactions in the three sample tubes were terminated by adding $1 \mathrm{~mL}$ of $10 \%$ trichloroacetic acid (TCA) to each of the tubes (i.e. both sets of three effect tubes containing $0.2 \mathrm{~mL}$ of the crude protease and $0.8 \mathrm{~mL}$ of azocasein substrate solution and the set of three blank test tubes). The TCA inactivated the enzyme and terminated potential autolysis, which may have occurred in the blank tubes. Immediately after TCA addition, $0.8 \mathrm{~mL}$ of azocasein-substrate solution was added to each of the three blank test tubes. Peptidase activity was prevented in the blanks by inactivating the enzyme prior to adding the substrate.

All the tubes (both effect and blanks) were removed from the water bath and allowed to stand for $20 \mathrm{~min}$ at room temperature. Then the precipitated materials in the test tubes were pelleted down by centrifuging at $5,000 \mathrm{rpm}$ for $10 \mathrm{~min}$ at room temperature $(28 \pm$ $2^{\circ} \mathrm{C}$ ). The products were quantified by transferring 1 $\mathrm{mL}$ of each resulting supernatant to another glass test tube containing $1 \mathrm{~mL}$ of $1 \mathrm{~N} \mathrm{NaOH}$ and their absorbances were measured in triplicates at $440 \mathrm{~nm}$ against water as reference. The mean blank absorbance value was subtracted from the mean sample absorbance values of the different crude protease solutions to give the amount of peptide product during the $10 \mathrm{~min}$ reaction period. The activity unit was calculated by extrapolation from a calibration curve of azocasein using subtilisin as standard enzyme. One protease unit was defined as the amount of crude enzyme required to produce a unit change in absorbance of TCA-soluble peptides in one minute under the assay conditions.

\subsection{Effect of water soluble fraction (WSF) of crude oil on protease biosynthesis and activity \\ 2.10.1 Preparation of WSF of crude oil}

Water soluble fraction (WSF) of Qua Iboe light crude oil was prepared using the procedure of Phatarpekar and Ansari [17]. Briefly, one part of crude oil was added to eight parts of de-ionized water in a $1 \mathrm{~L}$ Erlenmeyer flask. The flask was tightly capped with a stopper and covered with aluminum foil to reduce evaporation of volatile petroleum fractions. The mixture was stirred at low speed with a magnetic stirrer for $20 \mathrm{~h}$ at room temperature. The mixture was then emptied into a sterile separator funnel provided with a draining port and allowed to stand for $8 \mathrm{~h}$ for oil and water phases to separate. Finally, the aqueous phase was drained into a sterile Erlenmeyer flask and designated $100 \%$ stock solution of WSF.

\subsubsection{Estimation of hydrocarbon composition in WSF of crude oil}

The $100 \%$ stock solution of WSF of crude oil was analyzed using an Agilent 7890A gas chromatograph with a flame ionization detector (Agilent 7890A GCFID). The carrier gas was helium while nitrogen was used as the makeup gas. The 100\% WSF stock solution was analyzed for concentrations of total petroleum hydrocarbons (TPH), monoaromatic (MAH) and polyaromatic hydrocarbons (PAH).

\subsubsection{Preparation of different concentrations of WSF of crude oil}

Different per cent concentrations of water soluble fraction of crude oil were prepared by dilution of the $100 \%$ stock solution according to the method of Rodrigues et al. [19]. Based on preliminary range finding toxicity tests, the WSF concentrations (\%) were $0,10,20,30,40,50,60,70,80,90,100$ (Table 1). De-ionized water served as diluent and the various WSF concentrations were filter-sterilized using $0.45 \mu \mathrm{m}$ pore size Millipore membrane filter.

\subsubsection{Effect of WSF of crude oil on protease biosynthesis}


The general toxicity assay protocols included (i) cell growth (ii) cell washing (iii) induction of protease biosynthesis (iv) exposure of proteasebiosynthesizing cells to different concentrations of WSF [14] (v) resumption of protease biosynthesis in skimmed-milk minimal medium,

Step 1: Efficient proteolytic bacteria were grown in TSB in $100 \mathrm{~mL}$ Erlenmeyer flasks. Flasks were incubated at room temperature on a rotary shaker agitating at $100 \mathrm{rpm}$ for $18 \mathrm{~h}$.

Step 2: The 18 h-old cells were harvested by centrifugation at $5000 \mathrm{rpm}$ for $10 \mathrm{~min}$ and washed twice in sterile de-ionized distilled water and then standardized to $10^{8}$ cells $/ \mathrm{mL}$ using McFarland standards for inoculum preparation as described by Chapin and Lauderdale [3].

Table 1 Preparation of different concentrations of water soluble fraction of crude oil

\begin{tabular}{ccc}
\hline$\%$ concentration of WSF & Volume of solution $(\mathrm{mL})$ & Volume of diluent $(\mathrm{mL})$ \\
\hline 0 & 0 & 5 \\
10 & 0.5 & 4.5 \\
20 & 1 & 4 \\
30 & 1.5 & 3.5 \\
40 & 2 & 3 \\
50 & 2.5 & 2.5 \\
60 & 3 & 2 \\
70 & 3.5 & 1.5 \\
80 & 4 & 1 \\
90 & 4.5 & 0.5 \\
100 & 5 & 0 \\
\hline
\end{tabular}

Step 3: Zero-point two milliliter $(0.2 \mathrm{~mL})$ of washed bacterial cell suspension was added to $9.8 \mathrm{~mL}$ of skimmed-milk-minimal medium in $50 \mathrm{~mL}$ Erlenmeyer flasks and flasks incubated at room temperature on a rotary shaker agitating at $100 \mathrm{rpm}$ for $2 \mathrm{~h}$. Thereafter, reaction mixture was centrifuged; protein determinations made from supernatants and cell pellets washed and re-suspended in sterile deionized distilled water.

Step 4: Washed cell suspensions from step 4, $1 \mathrm{~mL}$ each, was added to a set of 3 tubes containing an equal volume of different concentrations of WSF. The tubes were incubated in tube shaker at room temperature for $1 \mathrm{~h}$. Thereafter, tube contents were centrifuged, pellets washed and re-suspended in sterile de-ionized distilled water.

Step 5: Re-suspended washed cells were added to $49 \mathrm{~mL}$ of skimmed milk-minimal medium at $2 \%$ $(\mathrm{v} / \mathrm{v})$ in $250 \mathrm{~mL}$ Erlenmeyer flasks and flasks incubated at room temperature on a rotary shaker agitating at $150 \mathrm{rpm}$ for $96 \mathrm{~h}$ to resume protease biosynthesis, if possible. Aliquots of $2 \mathrm{~mL}$ were withdrawn every $2 \mathrm{~h}$ for the first $12 \mathrm{~h}$ and then every $12 \mathrm{~h}$ for the remaining $84 \mathrm{~h}$ to determine protease concentration as described in section 2.5. Data was subjected to regression analysis and median inhibition concentration (IC50) of the water soluble fraction was determined.

\subsubsection{Effect of WSF of crude oil on protease activity}

Here, the method described by Usharani and Muthuraj [23] was employed. The effect of the various concentrations of WSF of crude oil on protease activity was determined by the addition of 1 $\mathrm{mL}$ of various concentrations of WSF to $1 \mathrm{~mL}$ of the cell-free supplements in the reaction mixture as outlined in section 2.4 and incubation at $30^{\circ} \mathrm{C}$ in a water bath for $10 \mathrm{~min}$. Proteolytic activity was quantified with azocasein as substrate.

\subsubsection{Crude oil biodegradation studies}

The degradation of Qua Iboe light crude oil was studied in shake flasks. The medium was as described in section 2.3. Firstly, a mixed-culture degradation study was set up containing all three bacteria with either casein or $\mathrm{NH}_{4} \mathrm{Cl}$ as nitrogen source. Secondly, sterile crude protease solutions from respective bacteria were added at $1 \%, 2 \%, 3 \%, 4 \%$ and $5 \%$ to $50 \mathrm{~mL}$ sterile (autoclaved at $121^{\circ} \mathrm{C}$ for $15 \mathrm{~min}$ ) minimal medium containing $1 \%(\mathrm{w} / \mathrm{v})$ casein-N in $250 \mathrm{~mL}$ Erlenmeyer flask. The carbon source in both studies was $40 \% \mathrm{WSF}$ and was added at $50 \%(\mathrm{v} / \mathrm{v})$. Overnight tryptic soy broth cultures of MWPB18, OWPB63 and OWPB17 were each added to corresponding flasks at $2 \%(\mathrm{v} / \mathrm{v})$. All arrangements were made in triplicates. Flasks were incubated at room temperature on an orbital shaker agitating at $120 \mathrm{rpm}$ for 16 days. Extent of degradation was evaluated by carbon (IV) oxide evolution method.

\subsubsection{Statistical analysis}


Statistical analyses of data were performed with Excel 2007 software with significant levels set at 5\% $(P=0.01$ and 0.05$)$. Significant means were compared using $t$-test for two samples assuming unequal variances.

\section{Results}

\subsection{Distribution of bacteria in samples}

Results of distribution of bacteria in samples revealed that culturable aerobic bacterial counts of sediments from all three sampling points were in the order of $10^{8} \mathrm{cfu} / \mathrm{g}$ while water samples had counts between $10^{6}$ and $10^{7} \mathrm{cfu} / \mathrm{mL}$. Details of the result are presented in Table 2. The table also reveals that sediment samples haboured higher numbers of morphologically-distinct colonies than corresponding water samples, and that the un-impacted samples of Mkpanak contributed $56.71 \%$ (water + sediment) of the total number of distinct colonies isolated in this study. Correlation analysis revealed a non-significantly weak relationship $(P=0.222 ; R=0.5852)$ between bacterial count and number of distinct colonies from samples. Table 2 also shows that only $10.04 \%$ of the variety of bacteria from all samples could utilize crude oil as sole source of carbon and energy but that $24.73 \%$ of distinct colonies could elaborate protease using skimmed milk as substrate. A two-factor analysis of variance (without replication) revealed that there was no significant difference $(P=0.542)$ among sampling points but that significant difference $(P=0.034)$ existed between sediment and water samples in terms of percent number of protease producers.

\subsection{Quantitative screening of bacteria for protease production}

Results of the experiments set up to quantify amounts of protease expressed as protease production potential (\%) in primary positive bacteria are presented in Table 3 and Figure 3. Table 3 reveals that all 15 isolates that met the $30 \mathrm{~mm}$ cut-off mark also had at least $70 \%$ protease production potential but that only $6(40 \%)$ of the 15 bacteria were positive in the Bradford protein detection test. However, only 3 isolates namely MKW18, OKW4 and OKW17 could produce protease at concentrations that could be detected by spectrophotometric analysis. The protease amounts were $21.53 \pm 0.97,58.31 \pm 0.67$ and $33.79 \pm 1.05 \mu \mathrm{g} / \mathrm{mL}$ respective MKW18, OKW4 and OKW17. These isolates also had crude oil biodegradation abilities of $34.58,48.64$ and $38.75 \mathrm{mg}$ $\mathrm{C}-\mathrm{CO}_{2}$ respectively. Concentration of protein in test samples was determined from standard curve using the modified regression equation;

$$
x=\frac{y-\frac{0.0718}{0.0087}}{0.3}
$$

Eqn 3 where $x$ is the protein concentration, $y$ the absorbance reading of test sample and 0.3 , a constant value of volume $(\mathrm{mL})$ of test sample with which absorbance readings were made.

\subsection{Identification of protease-producing bacteria}

The three protease-producing isolates, MKW18, OKW4 and OKW17 were identified by morphological, biochemical and molecular characterizations as Serratia sp.MKW18, Vibrio fluvialis OKW4 and Pseudomonas fluorescence OKW17. Their identities are presented in Table 4. The table shows that Serratia sp.MKW18 had 100\% sequence homology with Serratia sp. Strain ZJ-1 with Genbank accession number JQ954966A, Vibrio fluvialis OKW4 had 99\% similarity with Vibrio fluvialis Strain ESP56180 with Genbank accession number JQ650110A while Pseudomonas fluorescence OKW17 had 96\% sequence homology with Pseudomonas fluorescence Strain 25. The isolates were deposited in the University of Calabar Collection of Microorganisms (UCCM) as Serratia sp.MWPB18 UCCM 0008, Vibrio fluvialis OWPB63 UCCM 0004 and Pseudomonas fluorescence OWPB17 UCCM.

\subsection{Time-course of protease production by selected bacteria}

Results of the time-course for protease production by bacteria are presented in Table 5, Figures 2 and 3 . The table reveals that all three bacteria initiated protease production within $2 \mathrm{~h}$ of incubation. Figure 2 shows that Vibrio fluvialis OWPB63 produced the largest amount of protease throughout the duration of incubation and reached peak production by $48 \mathrm{~h}$ while the remaining two bacteria attained peak production at $60 \mathrm{~h}$. The productivity plot of Figure 3 nevertheless revealed that a peak productivity of $4.12 \mu \mathrm{g} / \mathrm{mL} / \mathrm{h}$ was attained by Vibrio fluvialis OWPB63 at $12 \mathrm{~h}$. The other two bacteria, Serratia sp.MWPB18 and Pseudomonas fluorescence OWPB17 reached their peak productivities of 0.73 and $1.12 \mu \mathrm{g} / \mathrm{mL} / \mathrm{h}$ at 36 and $48 \mathrm{~h}$ respectively. A twofactor analysis of variance revealed that there was significant influence of both time of incubation $(P=$ $0.000184)$ and type of bacterium involved in the proteolysis $(P=1.31 \mathrm{E}-05)$. Second-order polynomial regression analyses established significant $(P<0.05)$ relationship between incubation time and amount of protease by Serratia sp.MWPB18 $\left(R^{2}=0.9281\right)$, Vibrio fluvialis OWPB63 $\left(R^{2}=0.9636\right)$ and Pseudomonas fluorescence OWPB17 $\left(R^{2}=0.9727\right)$.

3.5 Effect of water soluble fraction of crude oil on protease biosynthesis 
The results of the gas chromatographic analysis of the water soluble fraction (WSF) of Qua Iboe light crude oil are presented as Figures $4 \mathrm{~A}, \mathrm{~B}$ and $\mathrm{C}$. Figure $4 \mathrm{~A}$ presents the chromatogram for total petroleum hydrocarbons (TPH) in the WSF and reveals a TPH concentration of $18.2 \mathrm{mg} / \mathrm{L}$ with $\mathrm{nC}_{15^{-}}$ $\mathrm{nC}_{19} \quad$ constituting $54.94 \%$ of the soluble hydrocarbons. Figure 4B on the other hand presents the chromatogram for monoaromatic hydrocarbon (MAH) components of the WSF with a total concentration of $8.81 \mathrm{mg} / \mathrm{L}$ and benzene contributing the highest proportion of $53.69 \%$. The chromatogram for polyaromatic hydrocarbon (PAH) fractions of the
WSF is presented as Figure 4C, with a total PAH concentration of $1.31 \mathrm{mg} / \mathrm{L}$.

The toxicity patterns of WSF of crude oil to bacterial protease biosynthesis are presented as Figure 5. Results of this study revealed that peak productivity and maximum protease production were affected by different concentrations of WSF in all three bacteria. Whereas acclimation periods increased with increase in toxicant concentrations, productivity and maximum achievable protease concentration decreased. In Figure 5A, Vibrio fluvialis OWPB63; the most and best proteolytic bacterium in this study had an acclimation period of $4 \mathrm{~h}$ (data not

Table 2 Distribution of bacteria in samples

\begin{tabular}{|c|c|c|c|c|c|c|c|}
\hline \multirow[t]{2}{*}{ Parameters } & \multicolumn{3}{|c|}{ Sediment } & \multicolumn{3}{|c|}{ Water } & \multirow[b]{2}{*}{ Total } \\
\hline & Mkpanak & Okposo & Utan Iyatah & Mkpanak & Okposo & Utan Iyatah & \\
\hline $\begin{array}{l}\text { Total } \\
\text { culturable } \\
\text { aerobic } \\
\text { bacterial count } \\
(\mathrm{cfu} \pm \mathrm{SD})\end{array}$ & $\begin{array}{c}4.12( \pm 0.85) \mathrm{x} \\
10\end{array}$ & $\begin{array}{c}2.75( \pm 0.53) \times \\
10\end{array}$ & $\begin{array}{c}2.35(\underset{8}{( \pm 06) \times}) \\
10\end{array}$ & $\begin{array}{c}3.66( \pm 0.6) \mathrm{x} \\
10\end{array}$ & $\begin{array}{c}2.20(\underset{6}{ \pm 0.74) x} \\
10\end{array}$ & $\begin{array}{c}1.38( \pm \underset{7}{(0.69)} \mathrm{x} \\
10\end{array}$ & \\
\hline $\begin{array}{l}\text { Number of } \\
\text { distinct } \\
\text { colonies }\end{array}$ & 78 & 37 & 29 & 57 & 65 & 13 & 279 \\
\hline $\begin{array}{l}\text { Percent (\%) } \\
\text { number of } \\
\text { distinct } \\
\text { colonies of } \\
\text { bacteria }\end{array}$ & 32.77 & 15.55 & 12.18 & 23.94 & 10.08 & 5.46 & \\
\hline $\begin{array}{l}\text { Number of } \\
\text { HUB }\end{array}$ & 2 & 9 & 7 & 1 & 7 & 2 & 28 \\
\hline $\begin{array}{l}\text { Percent }(\%) \\
\text { number of } \\
\text { HUB }\end{array}$ & 2.56 & 24.32 & 24.14 & 1.75 & 10.77 & 15.38 & 10.04 \\
\hline $\begin{array}{l}\text { Number of } \\
\text { protease } \\
\text { positive } \\
\text { bacteria }\end{array}$ & 12 & 7 & 5 & 27 & 10 & 8 & 69 \\
\hline $\begin{array}{l}\text { Percent }(\%) \\
\text { number of } \\
\text { protease } \\
\text { positive } \\
\text { bacteria }\end{array}$ & 15.38 & 18.92 & 17.24 & 47.37 & 41.67 & 61.54 & 24.73 \\
\hline
\end{tabular}

MKS-Mkpanak sediment; MKW-Mkpanak water; OKS-Okposo sediment; OKW-Okposo water; UYS-Utan Iyatah sediment; UYW-Utan Iyatah water, HUB-Hydrocarbon utilizing bacteria; cfu-Colony forming units per milliliter or colony forming units per gram; SD-Standard deviation

Table 3 Quantitative screening of hydrocarbonoclastic bacteria for protease production in submerged culture 
Water Soluble Fraction of Crude Oil Uncouples Protease Biosynthesis and Activity in Hydrocarbonoclastic Bacteria; Implications for Natural Attenuation

\begin{tabular}{|c|c|c|c|c|c|}
\hline $\mathrm{S} / \mathrm{N}$ & $\begin{array}{l}\text { Isolate } \\
\text { code }\end{array}$ & $\begin{array}{l}\text { Amount of } \\
\mathrm{CO}_{2}(\mathrm{mg})\end{array}$ & $\begin{array}{l}\text { Protease production } \\
\text { potential }(\%)\end{array}$ & $\begin{array}{l}\text { Bradford } \\
\text { test }\end{array}$ & $\begin{array}{l}\text { Amount of protease } \\
(\mu \mathrm{g} / \mathrm{mL})\end{array}$ \\
\hline 1 & MKS5 & $20.79 \pm 1.63$ & 74.63 & - & - \\
\hline 2 & MKS8 & $16.73 \pm 0.95$ & 79.15 & - & - \\
\hline 3 & MKW3 & $25.54 \pm 1.16$ & 75.92 & - & - \\
\hline 4 & MKW11 & $21.62 \pm 1.24$ & 76.87 & + & - \\
\hline 5 & MKW18 & $34.58 \pm 0.78$ & 90.10 & + & $21.53 \pm 0.97$ \\
\hline 6 & MKW22 & $27.83 \pm 1.78$ & 82.99 & - & - \\
\hline 7 & OKS7 & $23.06 \pm 0.91$ & 85.08 & - & - \\
\hline 8 & OKW4 & $48.64 \pm 1.05$ & 95.20 & + & $58.31 \pm 0.67$ \\
\hline 9 & OKW5 & $12.89 \pm 0.68$ & 70.85 & - & - \\
\hline 10 & OKW8 & $18.86 \pm 1.07$ & 70.17 & - & - \\
\hline 11 & OKW10 & $38.75 \pm 0.95$ & 84.95 & + & $33.79 \pm 1.05$ \\
\hline 12 & UYS3 & $21.86 \pm 1.11$ & 84.58 & - & - \\
\hline 13 & UYW1 & $17.43 \pm 0.89$ & 74.18 & - & - \\
\hline 14 & UYW3 & $28.67 \pm 1.77$ & 86.48 & + & - \\
\hline \multirow[t]{2}{*}{15} & UYW6 & $23.56 \pm 1.36$ & 78.29 & + & - \\
\hline & Blank & & & - & - \\
\hline
\end{tabular}

MKS-Mkpanak sediment; MKW-Mkpanak water; OKS-Okposo sediment; OKW-Okposo water; UYS-Utan Iyatah sediment; UYW-Utan Iyatah water. Values are means of triplicate determinations

Table 4 Identities of select proteolytic bacteria

\begin{tabular}{|c|c|c|c|c|c|c|c|}
\hline $\mathrm{S} / \mathrm{N}$ & $\begin{array}{l}\text { Isolate } \\
\text { code }\end{array}$ & $\begin{array}{l}\text { Gram } \\
\text { reaction }\end{array}$ & $\begin{array}{l}\text { Cell } \\
\text { shape }\end{array}$ & Pigmentation & $\begin{array}{l}\text { 16S rRNA } \\
\text { identity }\end{array}$ & $\begin{array}{c}\text { Close relative accession } \\
\text { number }\end{array}$ & $\%$ similarity \\
\hline 1 & MKW18 & - & Rod & Red & Serratia sp. & $\begin{array}{c}\text { Serratia sp. Strain ZJ-1 } \\
\text { (JQ954966 A) }\end{array}$ & $100 \%$ \\
\hline 2 & OKW4 & - & Rod & Cream & Vibrio fluvialis & $\begin{array}{l}\text { Vibrio fluvialis Strain } \\
\text { ESP56180 (JQ650110 A) }\end{array}$ & $99 \%$ \\
\hline 3 & OKW10 & - & Rod & Green & $\begin{array}{l}\text { Pseudomonas } \\
\text { fluorescence }\end{array}$ & $\begin{array}{c}\text { Pseudomonas } \\
\text { fluorescence Strain } 25\end{array}$ & $96 \%$ \\
\hline
\end{tabular}

MKW-Mkpanak water; OKW-Okposo water

Table 5 Time-course of bacterial protease production showing acclimation periods

\begin{tabular}{cccc}
\hline Time (h) & \multicolumn{2}{c}{ Protease concentration of bacteria $(\mu \mathrm{g} / \mathrm{mL} \pm$ standard deviation) } \\
\cline { 2 - 4 } & MWPB18 & OWPB63 & OWPB17 \\
\hline 0 & $0.00 \pm 0.00$ & $0.00 \pm 0.00$ & $0.00 \pm 0.00$ \\
2 & $0.06 \pm 0.01$ & $1.34 \pm 0.02$ & $0.28 \pm 0.04$ \\
4 & $0.19 \pm 0.02$ & $3.76 \pm 0.06$ & $0.49 \pm 0.18$ \\
6 & $0.38 \pm 0.02$ & $7.83 \pm 0.18$ & $1.05 \pm 0.27$ \\
8 & $0.89 \pm 0.03$ & $16.73 \pm 0.47$ & $2.33 \pm 0.45$ \\
10 & $1.75 \pm 0.02$ & $30.39 \pm 0.97$ & $5.38 \pm 0.38$ \\
12 & $3.87 \pm 0.14$ & $49.40 \pm 1.18$ & $12.84 \pm 0.73$ \\
24 & $7.98 \pm 0.57$ & $57.39 \pm 2.80$ & $21.77 \pm 1.03$ \\
36 & $16.73 \pm 1.63$ & $69.27 \pm 3.18$ & $34.92 \pm 1.78$ \\
48 & $25.39 \pm 1.89$ & $71.33 \pm 2.43$ & $48.34 \pm 2.21$ \\
60 & $32.76 \pm 1.92$ & $70.89 \pm 1.98$ & $50.04 \pm 2.06$
\end{tabular}


Water Soluble Fraction of Crude Oil Uncouples Protease Biosynthesis and Activity in Hydrocarbonoclastic Bacteria; Implications for Natural Attenuation

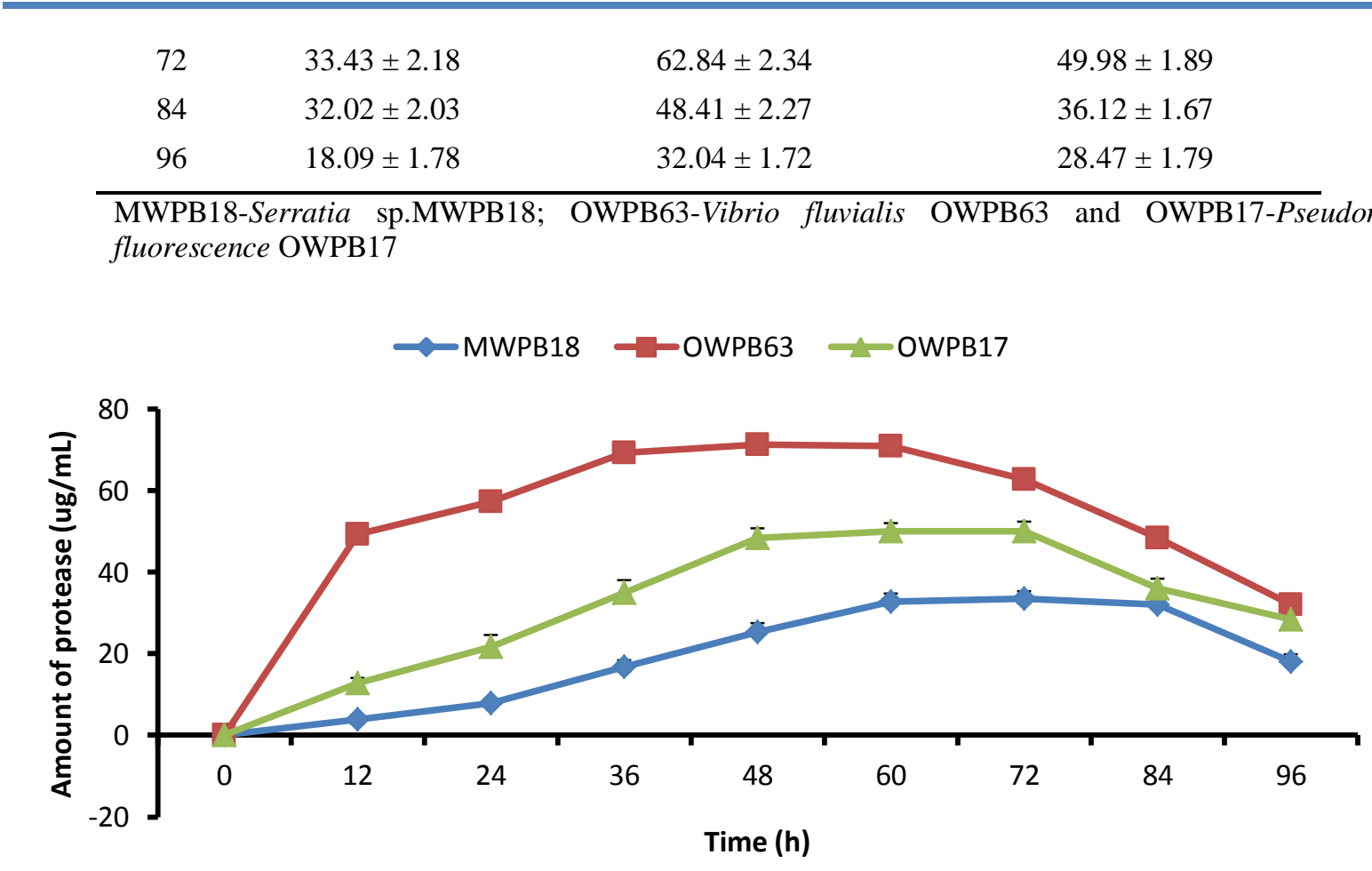

Fig.2 Time-course of protease production by bacteria in the absence of toxicant

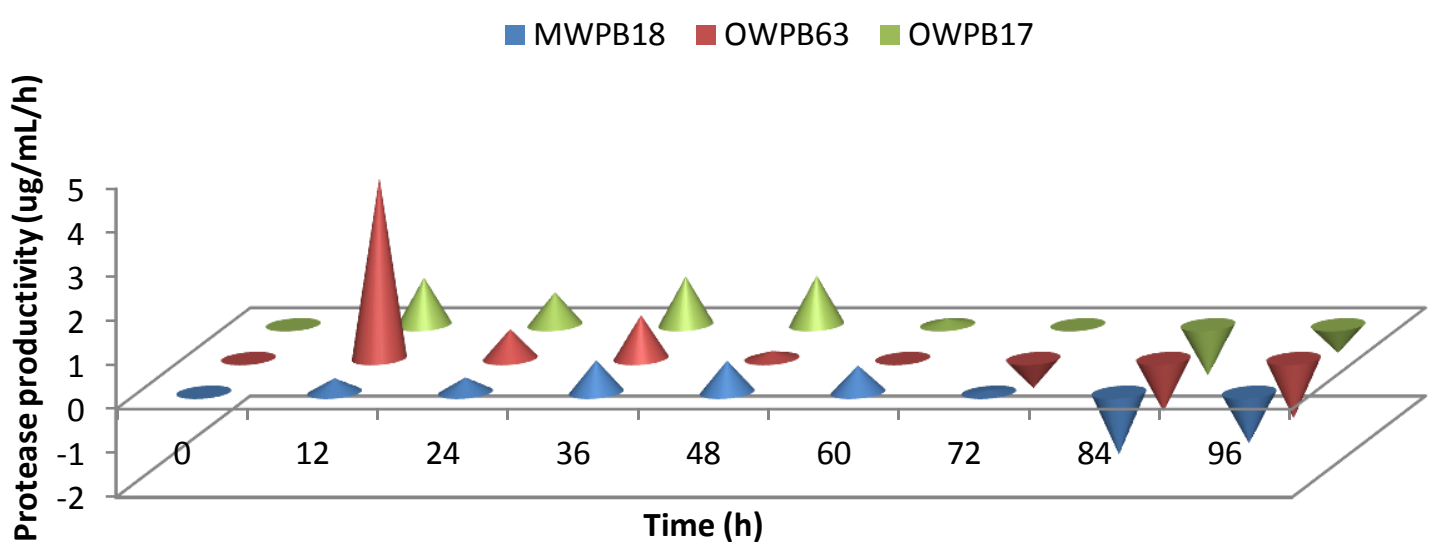

Fig.3 Bacterial protease productivity plot MWPB18- Serratia sp.MWPB18; OWPB63-Vibrio fluvialis OWPB63; OWPB17-Pseudomonas fluorescence OWPB17 

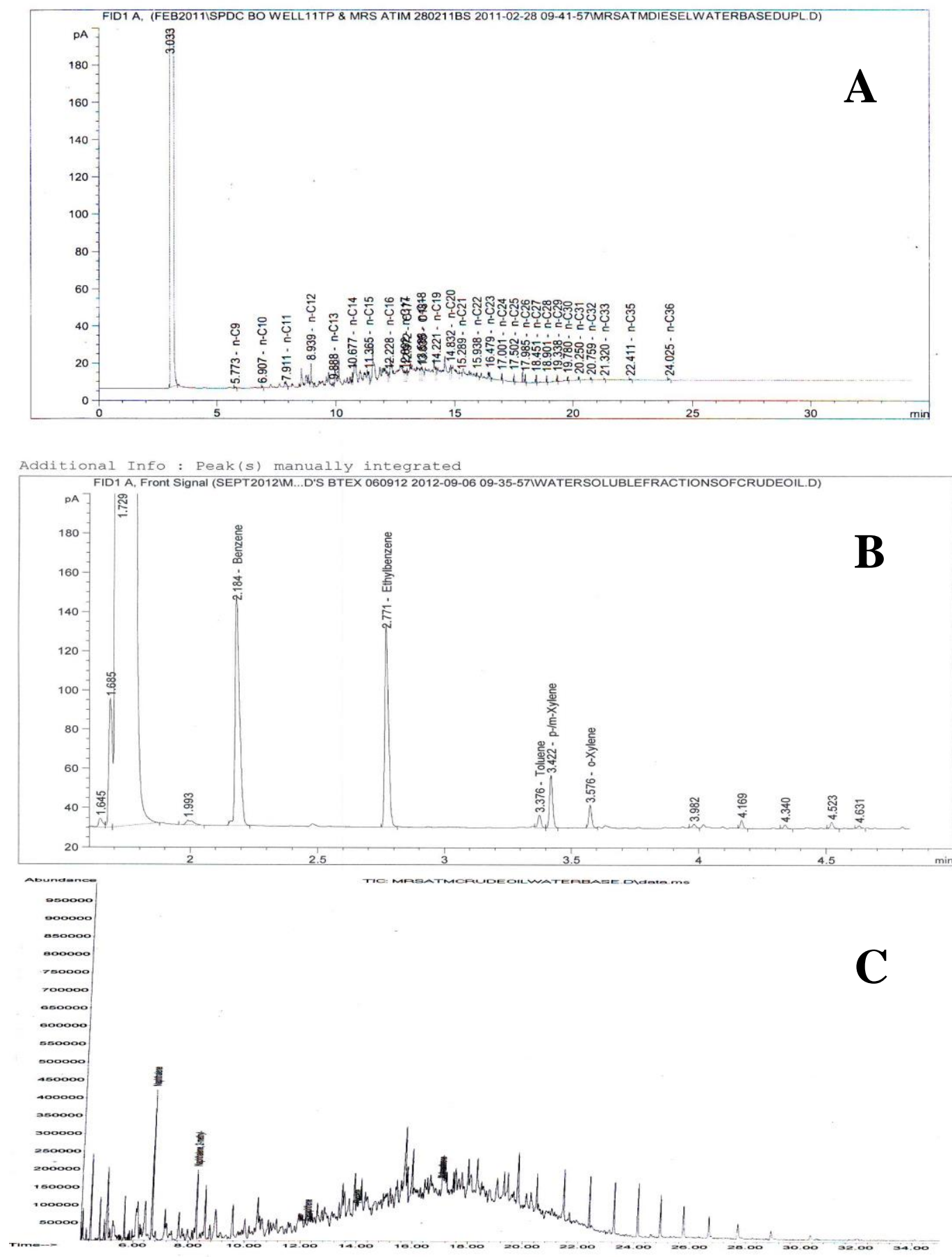

Fig. 4 Gas chromatograms of petroleum hydrocarbons in water soluble fraction of Qua Iboe light crude oil. A-Total Petroleum Hydrocarbon (TPH); B-Monoaromatic Hydrocarbons (MAH) and C-Polyaromatic Hydrocarbon (PAH)

shown) when exposed to $10 \%$ WSF with only 0.08 $\mu \mathrm{g} / \mathrm{mL}$ of protease compared to $1.34 \mu \mathrm{g} / \mathrm{mL}$ within 2 $\mathrm{h}$ in the control. Acclimation periods at WSF concentrations of $40 \%$ and above were greater than $12 \mathrm{~h}$. The bacterium reached peak protease biosynthesis of $31.67 \mu \mathrm{g} / \mathrm{mL}$ at $72 \mathrm{~h}$ when exposed to
$10 \%$ concentration of WSF compared to $71.33 \mu \mathrm{g} / \mathrm{mL}$ of the control at $48 \mathrm{~h}$. Protease production peaks could not be attained after exposure to WSF concentrations of $20 \%, 30 \%$ and $40 \%$ within the time frame $(96 \mathrm{~h})$ of the study. Peak productivity of the bacterium, when exposed to $10 \% \mathrm{WSF}$, was 1.03 
$\mu \mathrm{g} / \mathrm{mL} / \mathrm{h}$ attained at $60 \mathrm{~h}$ as compared to 4.12 $\mu \mathrm{g} / \mathrm{mL} / \mathrm{h}$ in the control indicating that biosynthesis was significantly $(P<0.01,0.05)$ affected by the toxicant.

The time taken to initiate protease biosynthesis in Serratia sp.MWPB18 (Figure 5B) was $6 \mathrm{~h}$ at $10 \%$ WSF (data not shown) and increased to $10 \mathrm{~h}$ when concentration increased to $20 \%$. Peak protease production of the bacterium occurred at $72 \mathrm{~h}$ in the control and upon exposure to only $10 \%$ concentration of WSF. When toxicant concentration increased to $20 \%$ and $30 \%$, peak production times extended to 84 and $96 \mathrm{~h}$ respectively. Acclimation periods for protease biosynthesis when bacterium was exposed to 40 and $50 \%$ WSF occurred at 60 and $72 \mathrm{~h}$ respectively.

In Figure 5C, Pseudomonas fluorescens OWPB17 had an acclimation period of $4 \mathrm{~h}$ (data not shown) at WSF concentrations of 30 and $40 \%$ which increased to $8 \mathrm{~h}$ when concentration of WSF increased to $50 \%$. Water soluble fraction concentrations of $10 \%, 20 \%$ and $30 \%$ all mediated peak protease production at 60 $\mathrm{h}$ in Pseudomonas fluorescens OWPB17 as in the control. Maximum protease concentration of $17.14 \mu \mathrm{g} / \mathrm{mL}$ was attained at $72 \mathrm{~h}$ when the bacterium was exposed to $40 \%$ concentration of WSF. Acclimation period of the bacterium when exposed to $60 \% \mathrm{WSF}$ was $24 \mathrm{~h}$ and peak protease production of $0.15 \mu \mathrm{g} / \mathrm{mL}$ at that toxicant concentration occurred at $60 \mathrm{~h}$.

\subsection{Effect of water soluble fraction of crude oil on protease activity}

Results of the effect of the various concentrations of WSF on protease activity are presented in Figure 6. One unit of enzymatic activity was defined as the amount of enzyme that increased the absorbance
$\left(\mathrm{A}_{440}\right)$ value of the assay reaction mixture (TCAsoluble peptides) by 0.1 in $1 \mathrm{~min}$. The figure shows that protease activity of all three decreased when challenged with incremental concentrations of WSF. Protease activity of Vibrio fluvialis OWPB63 decreased from $116.61 \mu \mathrm{g} / \mathrm{mL} / \mathrm{min}$ in the control to $432.9 \mu \mathrm{g} / \mathrm{mL} / \mathrm{min}$ when challenged with $100 \% \mathrm{WSF}$. The activity of protease in Pseudomonas fluorescens OWPB17 decreased from $145.84 \mu \mathrm{g} / \mathrm{mL} / \mathrm{min}$ in the control to $297.56 \mu \mathrm{g} / \mathrm{mL} / \mathrm{min}$ when exposed to $100 \%$ WSF while that for Serratia sp.MWPB18 decreased from $174.56 \mu \mathrm{g} / \mathrm{mL} / \mathrm{min}$ in the control to $248.95 \mu \mathrm{g} / \mathrm{mL} / \mathrm{min}$ when exposed to $100 \% \mathrm{WSF}$. A two-factor analysis of variance of data revealed significant influences of WSF concentrations $(P=$ $0.001)$ and nature of bacteria $(P=0.029)$ on protease activities. The figure also shows that activity of protease from Vibrio fluvialis OWPB63 was the most affected by toxicant concentrations and that from Serratia sp.MWPB18 was least affected.

\subsection{Confirmatory biodegradations studies}

Results of the pure-culture biodegradation studies are presented in Figure 7. The results showed that Pseudomonas fluorescens OWPB17 produced the highest amount of $\mathrm{C}-\mathrm{CO}_{2}$ of $34.7 \mathrm{mg}$ from $20 \% \mathrm{WSF}$ and that the biodegradation process was significantly $\left(P=1.46 \mathrm{E}-05 ; R^{2}=0.9922\right)$ influenced by crude protease concentration. Vibrio fluvialis OWPB63 protease was confirmed the most susceptible to toxicity by $20 \% \mathrm{WSF}$, releasing only $5.4 \mathrm{mg} \mathrm{C}-\mathrm{CO}_{2}$ in the degradation process which was significantly $(P$ $\left.=0.000 ; R^{2}=0.9690\right)$ influenced by its crude protease concentration. However, results of the mixed-culture degradation study showed that $98.4 \mathrm{mg} \mathrm{C}-\mathrm{CO}_{2}$ was liberated from $20 \%$ WSF when $\mathrm{NH}_{4} \mathrm{Cl}$ served as nitrogen source but only $13.8 \mathrm{mg}$ when casein-N served as nitrogen source. 

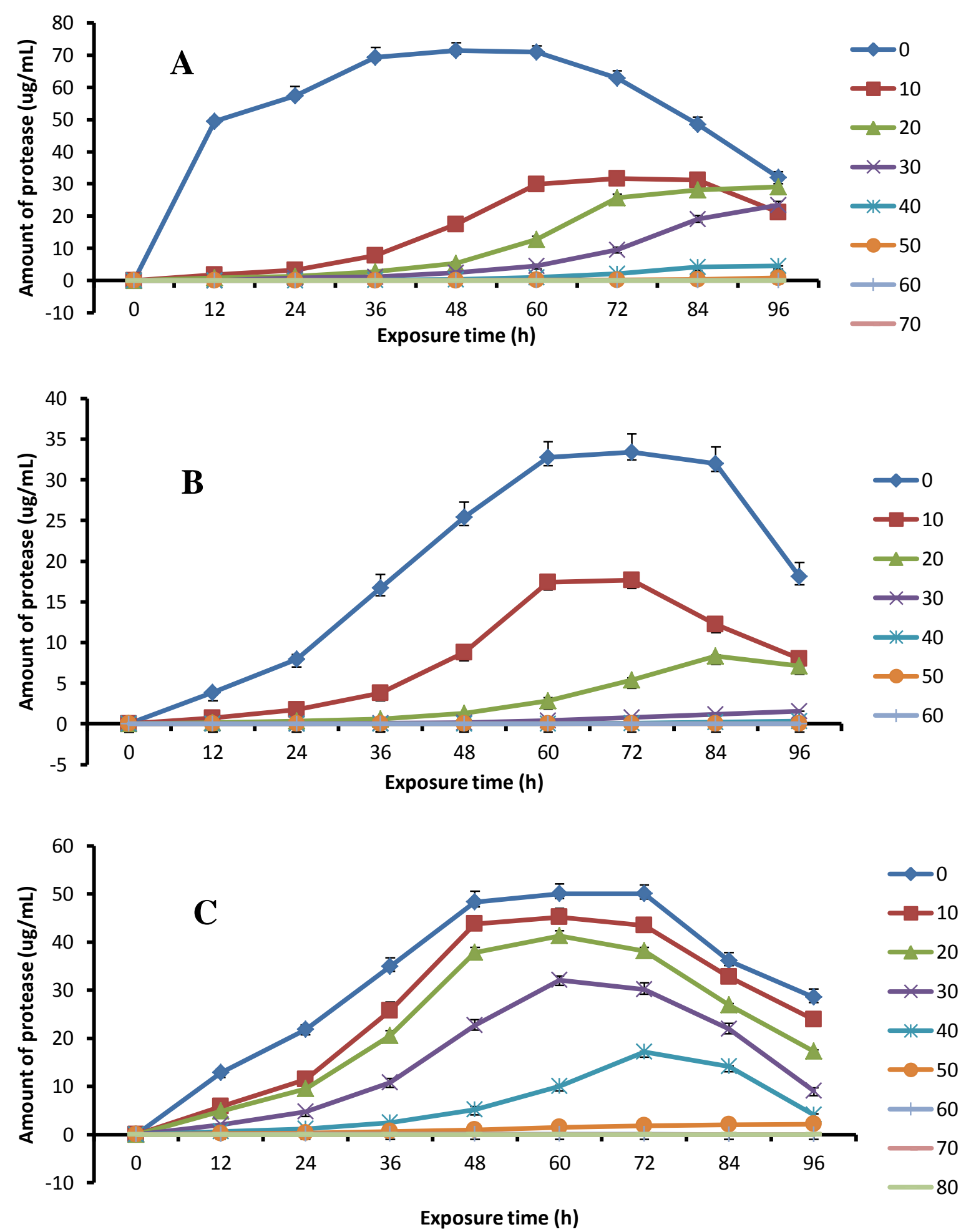

Fig. 5 Time-course of protease biosynthesis in (A) Vibrio fluvialis OWPB63 (B) Serratia sp. MWPB18 and (C) Pseudomonas fluorescens OWPB17 under crude oil water soluble fraction challenge 


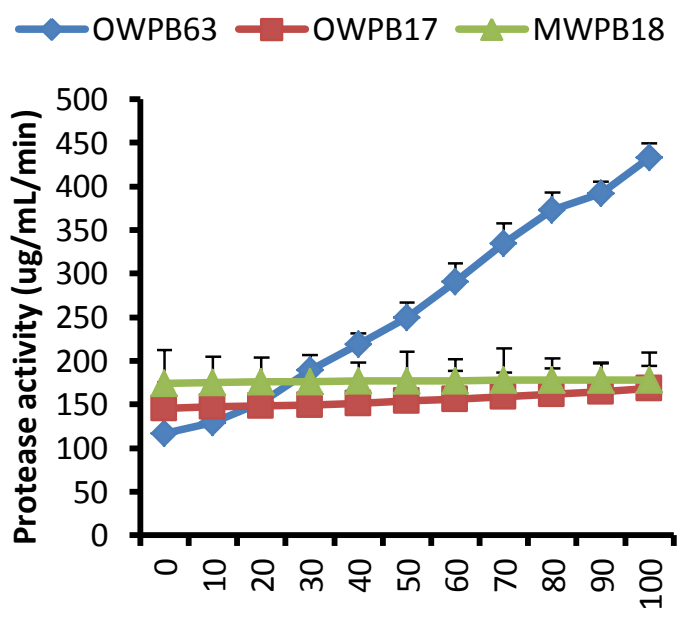

WSF concentration (\%)

Fig. 6 Effect of water soluble fraction of crude oil on protease activity. OWPB63-Vibrio fluvialis OWPB63; OWPB17-Pseudomonas fluorescence OWPB17; MWPB18-Serratia sp.MWPB18

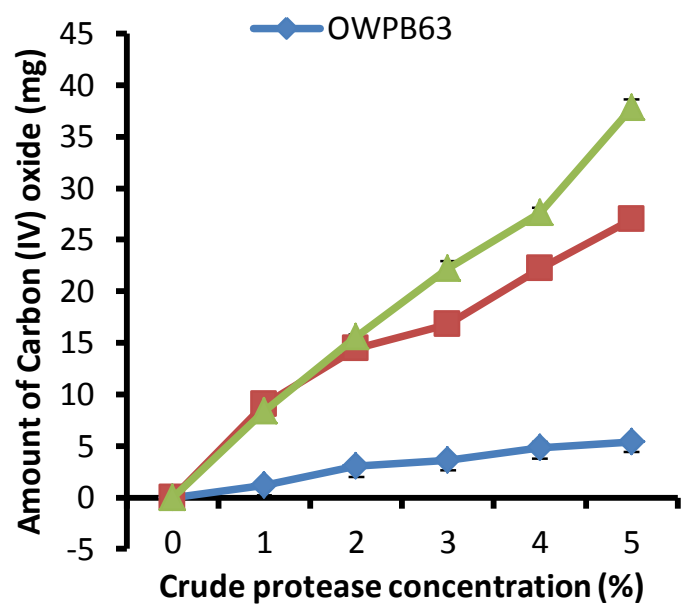

Fig.7 Crude protease-mediated degradation of $20 \%$ water soluble fraction of Qua Iboe light crude oil by respective bacteria using casein-N as nitrogen source. OWPB63-Vibrio fluvialis OWPB63; OWPB17-Pseudomonas fluorescence OWPB17; MWPB18-Serratia sp.MWPB18

\section{Discussion}

The results of bacterial distribution in samples (Table 2) indicate that more bacteria inhabit less-disturbed sediments than the turbulent water columns and that sediment samples habour greater diversity of bacteria than water samples. These could arise from sediments serving as sinks for a large number of substrates that direct the physiological expression of relevant genes. The un-impacted samples from Mkpanak showed the highest percentage of morphologically-distinct bacteria suggesting the presence of different kinds of substrates that support the growth and proliferation of a diverse physiological group of bacteria. The overall percentage of hydrocarbon degraders of $10.04 \%$ is in agreement with earlier researches that the proportion of hydrocarbon degraders is about $10 \%$ in polluted samples and between 0.1 and $1 \%$ in un-polluted samples [8, 24]. The higher proportions of hydrocarbon utilizers in sediments compared to corresponding water samples indicate the ability of sediments to keep, as sinks, large amounts of hydrocarbons from where the overlying water column becomes periodically re-impacted. As expected, the sediment samples from crude oilimpacted areas of Okposo and Utan Iyatah had higher proportions of hydrocarbon-utilizing bacteria indicating genetic and subsequent physiologic adaptations of the major bacterial community in the areas, to chronic contamination by petroleum hydrocarbon substrates.

The higher proportion of protease-positive bacteria in un-impacted waters of Mkpanak compared to crude oil-impacted locations of Okposo and Utan Iyatah could be as a result of lack of hydrocarbon pollutants in the environment suggesting high sensitivity of bacterial proteolytic genes and/or gene products to hydrocarbon pollution. However, these differences were not statistically significant. The higher percentage of protease-positive bacteria in water columns could be as a result of the high biodegradability level of proteinaceous substrates which do not endure to accumulate in sediments owing to their high turn-over rates. Again, these differences were not statistically significant at the confidence level (95\%) set to test the hypothesis.

Hydrocarbonoclastic bacteria from all three locations demonstrated production of large amounts of protease. This probably derives from the need for bulk production of the enzyme to circumvent the toxicity and hence inactivation by hydrocarbon pollutants. This speculation is confirmed in Table 3 where the best three hydrocarbon degraders are shown to also produce the highest amount of protease.

The identities of the bacteria namely Serratia sp.MWPB18, Vibrio fluvialis OWPB63 and Pseudomonas fluorescence OWPB17 did not indicate the traditional hydrocarbon-utilizing species of 
bacteria in the ecosystem supporting the superior molecular tool of $16 \mathrm{~S}$ rRNA sequencing in identifying microbial isolates involved in diverse physiological roles in environments. Vibrio fluvialis is particularly interesting as a hydrocarbon degrader in the Qua Iboe estuarine ecosystems in the Niger Delta of Nigeria. To the best of our knowledge, this is the first documented report on the hydrocarbonoclastic potential of this bacterium.

Bacterial proteases are generally regarded as primary metabolites being synthesized during the lag phase of growth. The result of our study was in agreement with the general consensus since all three bacteria synthesized protease within $2 \mathrm{~h}$ of incubation. Albeit, the protease productivity plot (Figure 3 ) showed that peak production was attained within $12 \mathrm{~h}$ in Vibrio fluvialis OWPB63 suggesting that although the enzyme is a necessary requirement for reproduction (exponential growth) in the bacterium, highest amount of the enzyme is actually synthesized during the exponential phase of growth (data not shown). This would be attributed the rise in biomass concentration owing to intense bacterial reproduction. This information would be useful for establishing the duration of fermentative protease production by the bacterium if it qualifies on all counts as an industrial bacterium for large-scale production of the enzyme. The continuous drop in protease productivity in the bacterium confirms the biochemical role of the metabolite as an organic catalyst required for the hydrolytic cleavage of endoexo-peptide bonds in proteinaceous substrates. The early disappearance of the enzyme from fermentation broth of Vibrio fluvialis OWPB63 indicates its high turn-over rate occasioned on the higher specific growth rate (data not shown) of the bacterium compared to the other two bacteria.

Proteases, including proteinases and peptidases, are hydrolases that catalyze the hydrolytic cleavage of peptide bonds in proteins with the sole objective of reducing substrate complexicity thereby facilitating the activities of deaminases to increase the availability of $\mathrm{NH}_{3}-\mathrm{N}$ in the environment. Literature on hydrocarbon research is replete with the requirement of nitrogen as a major limiting nutrient in hydrocarbon degradation. Successful hydrocarbonoclastic bacteria do so through synthesis of proteases which make nitrogen available in utilizable form. This is because available nitrogen $\left(\mathrm{NH}_{4}{ }^{+}\right)$frequently gets washed out in open systems [13]. Only about $0.02 \%$ of petroleum hydrocarbons are soluble in water [11] and this constitutes the biologically-available organic-carbon concentration that mediates bacterial growth and toxicity. In the present study, the water soluble fraction (WSF) of Qua Iboe light crude, with major compositions (g/L) of TPH 18.2; MAH 8.81; PAH 1.31, was found to be inhibitory to bacterial metabolism (data not shown), by uncoupling protein biosynthetic mechanisms and competitively inhibiting protease activity. This is understandable since the baseline concentration of TPH in the three ecosystems from where the bacteria were isolated was $<0.01 \mathrm{mg} / \mathrm{L}$. A $100 \%$ concentration $(9.1 \mathrm{mgTPH} / \mathrm{L})$ will appear too high to mediate all the physiological changes observed in this study. Similarly, a $50 \%$ concentration $(2.26 \mathrm{mgTPH} / \mathrm{L})$ which is several folds higher than the baseline concentration of $0.01 \mathrm{mg} / \mathrm{L}$ could also be toxic.

Specifically from this study, increasing concentrations of WSF of crude oil significantly inhibited protease biosynthesis in Vibrio fluvialis OWPB63. Since $10 \%(0.91 \mathrm{mg} / \mathrm{L})$ of WSF could reduce maximum protease concentration from 71.33 $\mu \mathrm{g} / \mathrm{mL}$ to $31.67 \mu \mathrm{g} / \mathrm{mL}$ ( $>50 \%$ inhibition), it follows that median inhibition concentration (IC50) of the WSF to Vibrio fluvialis OWPB63 was $<10 \%$. Since the bacterium proliferated in the petroleum contaminated environment as part of the hydrocarbon-degrading community, it follows that the concentration of toxic components of the laboratory-prepared WSF was way above the tolerable baseline concentration in the natural environment which permitted hydrocarbonoclasis. Activity of the protease was also very susceptible to intoxication by varying concentrations of WSF and showed significant $(\mathrm{P}<0.05)$ decrease with increasing toxicant concentrations. This suggests that both the protease biosynthetic gene and the gene product of this bacterium are susceptible to toxicity by WSF of crude oil. This agrees with the findings of Dutton et al. [5] who reported enzyme biosynthesis and activity as model parameters for microbial toxicity testing. In the confirmatory pure-culture hydrocarbon degradation test, $88.9 \%$ reduction in the amount of carbon (IV) oxide released was observed indicating uncoupling of the hydrocarbonoclastic process through poor supplementation of $\mathrm{NH}_{3}-\mathrm{N}$ during the process. The significant linear regression model $\left(P=0.000 ; R^{2}=0.9690\right)$ suggests that $96.9 \%$ of the mineralization process was due to crude protease of the bacterium.

Peak production of protease in Pseudomonas fluorescence OWPB17 occurred at $60 \mathrm{~h}$ and the IC50 of WSF at this period was $30-40 \%$. The protease activity in this bacterium was not significantly $(P>$ $0.01,0.05)$ affected by the toxicant. This was confirmed in the biodegradation study where only $2.45 \%$ of mineralization ability was inhibited by $20 \%$ 
WSF of crude oil. Significant strong correlation $(P$ $\left.=1.46 \mathrm{E}-05 ; R^{2}=0.9922\right)$ exists between crude protease concentration in this bacterium and amount of $\mathrm{C}-\mathrm{CO}_{2}$ evolved during the degradation process suggesting that $99.22 \%$ of the mineralization was due to crude protease concentration.

Peak production of protease in Serratia sp.MWPB18 occurred at $72 \mathrm{~h}$ and the IC50 at that period was $10 \%$. Nevertheless, enzyme activity was also not significantly $(P>0.01,0.05)$ affected by the toxicant suggesting once again that if the gene product was available for proteolysis, hydrocarbon degradation would go on uninhibited, all other factors remaining constant. Once again, these results were confirmed in the pure-culture degradation study where only $21.92 \%$ of mineralization ability was lost when challenged with $20 \%$ WSF of Qua Iboe light crude oil. The residual mineralization ability was significantly $\left(P=0.000 ; R^{2}=0.9651\right)$ mediated by the bacterium's crude protease (gene product).

The mixed-culture study revealed reduced mineralization of WSF of crude oil when casein-N served as nitrogen source compared to $98.4 \mathrm{mg} \mathrm{C}$ $\mathrm{CO}_{2}$ when $\mathrm{NH}_{4} \mathrm{Cl}$ served as nitrogen source. This result confirms toxicity of WSF to protease biosynthetic genes in all three bacteria.

\section{Conclusion}

Results from this investigation suggest that limited mineralization of crude oil could occur in chronically impacted areas when soluble concentrations of hydrocarbon are within tolerable limits of the relevant hydrocarbonoclastic community. On the contrary, in the event of an oil spill, natural attenuation of the receiving system would be very slow owing to the high carbon:nitrogen ratio occasioned by inhibition of protease biosynthetic genes which make unavailable, the concentration of nitrogen; a major limiting nutrient in organic matter degradation. Protease biosynthesis is more amenable to toxicity by WSF of crude oil, hence a better toxicity index than its activity.

\section{References}

1. Antai, S. P. \& Mgbomo, E. (1989). Distribution of hydrocarbon-utilizing bacteria in oil spill areas. Microbios Letters, 40: 137-143.

2. Bradford, M. M. (1976). A rapid and sensitive method for the quantitation of microgram quantities of protein utilizing the principle of protein-dye binding. Analytical Biochemistry, 72: 248-254.

https://doi.org/10.1016/0003-2697(76)90527-3

3. Chapin, K. C. \& Lauderdale, T. (2003). Reagents, stains and media: bacteriology In Murray, P. R., Baron, E. J., Jorgensen, J. H., Pfaller, M. A. and Yolken, R. H. (Eds.) Manual of Clinical Microbiology ( $8^{\text {th }}$ edition) (p. 358). Washington DC: ASM Press.
4. Das N. \& Chandran, P (2011). Microbial degradation of hydrocarbon contaminants: an overview. Biotechnology Research international, volume 2011. https://doi.org/10.4061/2011/941810

5. Dutton, R. J., Bitton, G. \& Koopman, B. (1988). Enzyme biosynthesis versus enzyme activity as a basis for microbial toxicity testing. Toxicity Assessment, 3, 245243. https://doi.org/10.1002/tox.2540030302

6. Ekpenyong, M. G. \& Antai, S. P. (2007). Influence of pH on cadmium toxicity to species of Bacillus (02 and 12) during biodegradation of crude oil. International Journal of Biological Chemistry, $\quad 1$ : $29-37$. https://doi.org/10.3923/ijbc.2007.29.37

7. Ekpenyong, M. G., Antai, S. P. \& Asitok, A. D. (2016). A Pseudomonas aeruginosa strain IKW1 produces an unusual polymeric surface-active compound in waste frying oilminimal medium. International Journal of Sciences, 5 (6): 108-123. https://doi.org/10.18483/ijSci.1064

8. Ekpenyong, M. G., Antai, S. P. \& Essien, J. P. (2007). Quantitative and qualitative assessment of hydrocarbon degrading bacteria and fungi in Qua Iboe Estuary, Nigeria. Research Journal of Microbiology, 2:415-425. https://doi.org/10.3923/jm.2007.415.425

9. Ekpenyong, M., Antai, S., Asitok, A. \& Ekpo, B. (2017). Response surface modeling and optimization of major medium variables for glycolipopeptide production. Biocatalysis and Agricultural Biotechnology, 10: 113-121. https://doi.org/10.1016/j.bcab.2017.02.015

10. Gulati, R., Saxena, R. K. \& Gupta, R. (1997). A rapid plate assay for screening L-asparaginase producing microorganisms. Letters in Applied Microbiology, 24: 23 26. https://doi.org/10.1046/i.1472-765X.1997.00331.X

11. Harayama, S., Kishira, H., Kasai, Y. \& Shutsubo, K. (1999). Petroleum biodegradation in marine environments. Journal of Molecular Microbiology and Biotechnology, 1, 63-70.

12. Itah, A. Y. \& Essien, J. P. (2005). Growth profile and hydrocarbonoclastic potential of microorganisms isolated from tarballs in the Bight of Bonny, Nigeria. World Journal of Microbiology and Biotechnology, 21: 1317-1322. https://doi.org/10.1007/s11274-004-6694-z

13. Leahy, J. G. \& Colwell, R. R. (1990). Microbial Degradation of hydrocarbons in the environment. Microbiological Reviews, 54: 305-315.

14. Odokuma, L. O. \& Akponah, E. (2008). Response of Nitrosomonas, Nitrobacter and Escherichia coli to drilling fluids. Journal of Cell and Animal Biology, 2, 4354.

15. Okoh, A. I. (2006). Biodegradation alternative in the cleanup of petroleum hydrocarbon pollutants. Biotechnology and Molecular Biology Review. 1 (2): 38-50.

16. Oluwasuji, O. (2007) "Internal colonialism and the national question in Nigeria: The Niger Delta restiveness", In: Oyekanmi, F.D. and Soyombo, O. (eds.) Society and Governance: The quest for legitimacy in Nigeria. Lagos: Department of Sociology, University of Lagos and Friedrich Ebert Stiftung, Lagos, Nigeria, Pp 67-79.

17. Phatarpekar, P. V. \& Ansari, Z.A. (2000). Comparative toxicity of water soluble fractions of four oils on the growth of a Microalga. Botanica Marina, 43, 367375. https://doi.org/10.1515/BOT.2000.037

18. Rodrigues, L. R., Teixeira, J. A. \& Oliveira, R. (2006). Lowcost fermentative medium for biosurfactant production by probiotic bacteria. Biochemical Engineering Journal, 32: 135-142. https://doi.org/10.1016/i.bej.2006.09.012

19. Rodrigues, R. V., Miranda-Filho, K. C., Gusmao, E. P., Moreira, C. M., Romano, L. A. \& Sampaio, L. A. (2010). Deleterious effects of water-soluble fraction of petroleum, diesel and gasoline on marine pejerrey Odontesthes argentinensis larvae. Science of the Total Environment, 408, 
Water Soluble Fraction of Crude Oil Uncouples Protease Biosynthesis and Activity in Hydrocarbonoclastic Bacteria; Implications for Natural Attenuation

2054-2059.

https://doi.org/10.1016/j.scitotenv.2010.01.063

20. Stotzky, C. (1965). Determination of carbon dioxide. In Madison, C. A. B (Ed.), Methods of Soil analysis Part 2; Chemical and Microbiological properties. American Society of Agronomy Inc, Madison, USA.

21. Thijsee,G. J. E. \& van der Linden, A. C. (1961). Iso-alkane oxidation by a Pseudomonas. Antonnie van Leeuwenhoek, 27: 171-179. https://doi.org/10.1007/BF02538437

22. Ukpong, I. (2008). Conflict resolution in the oil and gas industry's operational areas. Paper presented at NOSDRA's Stakeholders Consultative Workshop for the Oil and Gas Sector. $4^{\text {th }}-7^{\text {th }}$ August, 2008, Calabar, Nigeria.

23. Usharani, B. \& Muthuraj, M. (2010). Production and characterization of protease enzyme from Bacillus laterosporus. African Journal of Microbiology Research, 4, 1057-1063.

24. Van Hamme, J. D, Singh, A, \& Ward, O. P. (2003). Recent advances in petroleum microbiology. Microbiology and Molecular Biology Reviews, 67: 503-549.

https://doi.org/10.1128/MMBR.67.4.503-549.2003

25. Vazquez, S. C., Hernandez, E. \& MacCormack, M. P. (2008). Extracellular proteases from the Antartic marine Pseudoalteromonas sp. P96-47 strain. Revista Argentina de Microbiologia, 40, 63-71. 